\section{Yield Comparisons of Pulled and Cut Sweetpotato Plants}

\author{
Melvin R. Hall ${ }^{1}$ \\ Department of Horticulture, University of Georgia, Coastal Plain Experiment \\ Station, Tifton, GA 31793
}

Additional index words. Ipomoea batatas, transplants

\begin{abstract}
Sweetpotato [Ipomoea batatas (L.)] storage root yields were evaluated from $\approx 25$-cm transplants. The shoot apex was either removed or not removed from pulled (underground stem retained) and cut (underground stem removed) 'Georgia Jet' and 'Red Jewel' plants. The shoot apex was not removed from pulled and cut 'Jewel' plants on which the basal half was immersed or not immersed in calcium hypochlorite solutions. Cut plants of all three cultivars produced higher total marketable and U.S. no. 1 yields than pulled plants. However, neither removing the shoot apex from 'Georgia Jet' and 'Red Jewel' nor immersing the basal half of 'Jewel' plants in calcium hypochlorite solutions improved yields.
\end{abstract}

In the United States, the highest freshmarket price is paid for U.S. no. 1 grade (5 to $9 \mathrm{~cm}$ in diameter, 7.5 to $23 \mathrm{~cm}$ long) sweetpotato roots, and increasing the yield of this grade could increase profits. Field plantings of sweetpotato are established with plants that are pulled or cut from propagating beds or with vine cuttings that are cut from established plants (Edmond, 1971). The basal end of pulled plants is composed of stem tissue and fibrous roots that develop in the bedding medium. Cut plants are removed from the plant bed by cutting the stems to leave the underground portion attached to the parent root in the bedding medium. Transplanting cut plants reduces the transfer of diseases or insect pests from the parent root to the production field, and cut plants may be used commercially to produce "seed" roots for propagating plants. Cordner and Galeotti (1961) reported a lower average yield from cut plants than pulled plants, but Edmond (1971) reported similar yields from cut and pulled plants. However, some

Received for publication 15 Apr. 1992. Accepted for publication 14 Dec. 1992. This research was supported by state and Hatch funds allocated to the Georgia Agricultural Experiment Station. Mention of a trademark, proprietary product, or vendor does not imply endorsement by the Georgia Agricultural Experiment Station, nor criticism of similar products not mentioned. The cost of publishing this paper was defrayed in part by the payment of page charges. Under postal regulations, this paper therefore must be hereby marked advertisement solely to indicate this fact.

Associate Professor. growers indicate that cut plants produce higher total yields and an increased percentage of U.S. no. 1 grade roots compared with pulled plants. Other growers report that immersing the basal half of plants in a calcium hypochlorite surface sterilant solution before transplanting increases yields. These reports by growers have not been substantiated.

Removing the shoot apex from 'Georgia Jet' plants before transplanting them to pots increased storage root dry weight (Hall, 1987), but the effect of this practice on root yields has not been evaluated under field conditions.

The objectives of this work were to determine sweetpotato yields from transplants as type (with or without). nonsignificant, respectively. influenced by pulling or cutting sweetpotato plants from the bedded propagating roots and by removing the primary shoot apex.

Sweetpotato plants were propagated from bedded roots according to standard commercial practices (Granberry and McLaurin, 1990). For each experiment, plants $\geq 25 \mathrm{~cm}$ above the propagation bed were pulled. The length of the underground portion of stems ranged from 4 to $6 \mathrm{~cm}$. Pulled plants $25 \pm 0.5 \mathrm{~cm}$ long were left intact with the underground stem and associated fibrous roots (pulled plant with shoot apex). The shoot apexes were cut from other pulled plants to prepare $25-\mathrm{cm}$ lengths (pulled plant without shoot apex). The $25-\mathrm{cm}$ cut plants were prepared by removing the underground portion of stem (cut plant with shoot apex) or by removing both the underground portion of stem and the shoot apex (cut plant without shoot apex) from pulled plants. Plants were transplanted 8 to $10 \mathrm{~cm}$ deep (two to three nodes) and $30 \mathrm{~cm}$ apart in a Tifton loamy sand (fine-loamy, siliceous, thermic Plinthic Paleudults) in $7.6 \times 1.3-\mathrm{m}$ plots established according to standard cultural practices (Granberry and McLaurin, 1990). Plots were irrigated with $25 \mathrm{~mm}$ of water immediately after transplanting and as needed to maintain plant growth. After harvesting, marketable roots were sorted into grades: U.S. no. 1 (5 to $9 \mathrm{~cm}$ in diameter, 7.5 to $23 \mathrm{~cm}$ long), canner ( 2.5 to $5 \mathrm{~cm}$ in diameter, 5 to $18 \mathrm{~cm}$ long), and jumbo (exceeds length and diameter requirements of U.S. no. 1 grade). There were few cull roots produced, and their yield is not reported. Root yields for total marketable and U.S. no. 1 roots are reported.

'Georgia Jet' and 'Red Jewel' plants, pre-

Table 1. Total marketable and U.S. no. 1 root yields (in metric tons per hectare) and percent U.S. no. 1 yield of 'Georgia Jet' and 'Red Jewel' sweetpotato as influenced by plant type (pulled or cut) and shoot apex

\begin{tabular}{|c|c|c|c|c|c|c|}
\hline \multirow[b]{3}{*}{ Variable } & \multicolumn{3}{|c|}{ Georgia Jet } & \multicolumn{3}{|c|}{ Red Jewel } \\
\hline & \multicolumn{6}{|c|}{ Yield } \\
\hline & $\begin{array}{c}\text { Total } \\
\text { marketable }\end{array}$ & U.S. no. 1 & $\begin{array}{c}\text { U.S. no. } 1 \\
(\%)\end{array}$ & $\begin{array}{c}\text { Total } \\
\text { marketable }\end{array}$ & U.S. no. 1 & $\begin{array}{c}\text { U.S. no. } 1 \\
(\%)\end{array}$ \\
\hline \multicolumn{7}{|c|}{ Main effects } \\
\hline \multicolumn{7}{|l|}{ Plant type (P) } \\
\hline Pulled & 46.1 & 13.2 & 27.6 & 21.9 & 15.6 & 71.2 \\
\hline Cut & 56.7 & 17.2 & 30.4 & 27.2 & 20.9 & 77.0 \\
\hline Significance & $* *$ & $* *$ & NS & $*$ & $* *$ & * \\
\hline \multicolumn{7}{|c|}{ Shoot apex type (A) } \\
\hline With & 53.3 & 15.9 & 29.2 & 25.7 & 19.3 & 74.7 \\
\hline Without & 49.3 & 14.4 & 28.7 & 23.3 & 17.1 & 73.5 \\
\hline Significance & NS & NS & NS & NS & NS & NS \\
\hline \multicolumn{7}{|c|}{ Interaction } \\
\hline $\mathrm{P} \times \mathrm{A}$ & $* *$ & $* *$ & NS & NS & Ns & NS \\
\hline
\end{tabular}

${ }^{{ }^{*}, *, N s}$ Means within main effects within columns, or interactions, significant at $P \leq 0.01$ or 0.05 or 
pared by the four methods described, were transplanted on 22 and 23 May 1986, respectively. Cultivars were planted in separate sections of the same field to facilitate mechanical harvesting. 'Georgia Jet' was harvested 90 days after transplanting; 'Red Jewel' was harvested at 124 days. Yield data for each cultivar were subjected to separate analyses of variance with two plant types (pulled or cut) and two shoot apex types (with or without) in a 2 $\times 2$ factorial in a randomized complete block design with five replications.

Pulled or cut 'Jewel' plants with the shoot apex attached were either not immersed (control) or immersed for 1 or $5 \mathrm{~min}$ in a 500-or 1000-ppm calcium hypochlorite solution and transplanted 4 June 1986. Plots were harvested 120 days later and root yields were evaluated in a $2 \times 5$ factorial in a split plot design with plant types (pulled or cut) as main plots and calcium hypochlorite immersion treatments (control; $500 \mathrm{ppm}, 1$ or $5 \mathrm{~min} ; 1000$ ppm, 1 or $5 \mathrm{~min}$ ) as subplots in five replications. Immersion in calcium hypochlorite solutions did not influence storage root yield and is not discussed further.

Before analyses, data for weights in each experiment were subjected to square-root transformations to equalize variance. Percentage data were subjected to square-root arcsin transformations. Transformed means were backtransformed for presentation.

Cut 'Georgia Jet' plants tended to produce higher total marketable and U.S. no. 1 grade yields than pulled plants, but there were significant interactions between plant type and shoot apex type (Table 1). The percentage of total marketable 'Georgia Jet' yield graded as U.S. no. 1 was not affected by plant type or the primary shoot apex. There were high yields of jumbo-grade 'Georgia Jet' roots (data not shown). Earlier harvesting probably would have resulted in a higher U.S. no. 1 yield and a better evaluation of the influence of treatment factors on the percentage of total marketable 'Georgia Jet' yield that was graded as U.S. no. 1 .

Yields were similar when plants retained the shoot apex, but removing the shoot apex significantly reduced total marketable and U.S.

Table 2. Total marketable and U.S. no. 1 yield (in metric tons per hectare) of 'Georgia Jet' sweetpotato as influenced by plant type (pulled and cut) and shoot apex type (with or without).

\begin{tabular}{llcc}
\hline & & & Yield \\
\cline { 3 - 4 } $\begin{array}{l}\text { Plant } \\
\text { type }\end{array}$ & $\begin{array}{c}\text { Shoot } \\
\text { apex type }\end{array}$ & $\begin{array}{c}\text { Total } \\
\text { marketable }\end{array}$ & U.S. no. 1 \\
\hline Pulled & With & $51.4 \mathrm{~b}^{2}$ & $15.4 \mathrm{ab}$ \\
& Without & $41.1 \mathrm{c}$ & $11.2 \mathrm{~b}$ \\
Cut & With & $55.2 \mathrm{ab}$ & $16.6 \mathrm{a}$ \\
& Without & $58.1 \mathrm{a}$ & $17.9 \mathrm{a}$ \\
\hline
\end{tabular}

${ }^{2}$ Mean separation within columns by Duncan's multiple range test, $P \leq 0.05$.

Table 3. Total marketable and U.S. no. 1 root yields (in metric tons per hectare) and percent U.S. no. 1 yield of 'Jewel' sweetpotato as influenced by pulled and cut plants.

\begin{tabular}{lccc}
\hline \hline & & Yield & \\
\cline { 2 - 4 } Plant & Total & & U.S. no. 1 \\
type & marketable & U.S. no. 1 & $(\%)$ \\
\hline Pulled & 23.9 & 15.4 & 65.2 \\
Cut & 32.7 & 23.3 & 71.1 \\
Significance & $* *$ & $* *$ & Ns \\
\hline
\end{tabular}

$\overline{* *, \times s}$ Means within columns significant at $P \leq 0.01$ or nonsignificant, respectively.

no. 1 yields of pulled plants compared with cut plants (Table 2). Yields of cut 'Georgia Jet' plants were similar regardless of whether the shoot apex was removed. However, removing the shoot apex from pulled plants tended to reduce yield, and this reduction was significant for total marketable yield.

Total marketable, U.S. no. 1, and percent U.S. no. 1 yields of 'Red Jewel' were higher from cut than pulled plants, but presence of the shoot apex did not significantly influence yields (Table 1). Total marketable and U.S. no. 1 yields, but not percent U.S. no. 1 yield, of 'Jewel' were higher from cut than pulled plants (Table 3). Immersing 'Jewel' plants in calcium hypochlorite did not influence storage root yield (data not shown).

Sweetpotato transplant length influences yield (Godfrey-Sam-Aggrey, 1974). In the individual experiments described here, transplants that originated from the same propagating root source were of similar "size" (measured as length in these experiments) and were transplanted on the same date. Edmond (1971) described these conditions as essential for comparing pulled and cut plants. In contrast to previous reports (Cordner and Galeotti, 1961; Edmond, 1971), the present findings showed that cut plants usually yielded more total marketable and U.S. no. 1 roots than pulled plants. However, removing the primary shoot apex did not increase yields. In these tests, the potential for increasing sweetpotato root yields with cut plants was demonstrated with three cultivars. However, further research with these and additional cultivars maybe needed before generalizations can be made.

\section{Literature Cited}

Cordner, H.B. and C. Galeotti. 1961. Effects of length of growing season and method of propagating on yields in sweetpotatoes. Oklahoma State Univ., Processed Series P-392.

Edmond, J.B. 1971. Field production practices and operations, p. 123-147. In: J.B. Edmond and G.R. Ammerman (eds.). Sweet potatoes: Production, processing, and marketing. AVI, Westport, Conn.

Godfrey-Sam-Aggrey, W. 1974. Effects of cutting lengths on sweet potato yields in Sierra Leone. Experimental Agr. 10:33-37.

Granberry, D.M. and W.J. McLaurin. 1990. Sweet potato. Georgia Coop. Ext. Serv. Circ. 677.

Hall, M.R. 1987. Shoot apex and nodes exposed above-ground influenced growth of sweet potato vine cuttings. HortScience 22:230-232. 